\title{
PERILAKU CUCI TANGAN DI KALANGAN SISWA-SISWI SMAK SANTA AGNES SURABAYA
}

\author{
Eka Cipta Halim ${ }^{1}$, Oedojo Soedirham² \\ 1,2 Departemen Promosi Kesehatan dan Ilmu Perilaku \\ Fakultas Kesehatan Masyarakat, Universitas Airlangga \\ Alamat Korespondensi: Eka Cipta Halim \\ Email : nyetz_cipta@ymail.com
}

\begin{abstract}
Cleanliness is a state free of dirt, including dust, garbage and odors. Hygiene is also a lifestyle, and is also included in Clean and Healthy Lifestyle. Student always consumption of food after exercise can restore lost of body stamina. However, student often forget the Wash the Hand with Soap before eating food. Behavioral factors consist of supporting factors, enabling factors and strengthening factors. This purpose of study in order to know the knowledge, attitude and behavior of informants. The research was done at High School of Santa Agnes Surabaya by using descriptive method of qualitative approach. Instrument in this research is guidance of deep interview with informant amounted to 8 people. The variables in this study were the students' knowledge, the attitude of the students and the behavior of the students associated with the CTPS. Supporting factors consist of attitude and behavioral knowledge. Knowledge of students was in the low knowledge, because only limited to know. Attitudes toward the behavior of CTPS at SMAK Santa Agnes support CTPS as a beneficial healthy behavior. The behavior of CTPS at SMAK Santa Agnes was lacking, especially after sports. Possible factors in the form of facilities that have been good, but the number is still inadequate. The reinforcing factor of the teacher's encouragement to perform the CTPS and the motivation of the dirty hand-related sectional environment can lead to ill experiences of illness that have been experienced and are accustomed to CTPS. The conclusion that can be drawn is that all informants have diverse behavior and risk to their health. Lazy behavior is the main key that must be resisted so as not to interfere with health.
\end{abstract}

Keywords: antiseptic soap, high school students, hand washing behavior

\begin{abstract}
ABSTRAK
Kebersihan adalah keadaan yang bebas dari kotoran, termasuk debu, sampah dan bau. Kebersihan juga merupakan gaya hidup, dan juga termasuk dalam Gaya Hidup Bersih dan Sehat. Konsumsi makanan setelah berolahraga dapat mengembalikan daya tahan tubuh yang hilang. Namun, sering lupa Cuci Tangan dengan Sabun antiseptik sebelum makan makanan. Faktor perilaku terdiri dari faktor pendukung, faktor pemungkin dan faktor penguatan yang digunakan dalam penelitian ini untuk mengetahui pengetahuan, sikap dan perilaku informan. Penelitian ini dilakukan di SMA Santa Agnes Surabaya dengan menggunakan metode deskriptif pendekatan kualitatif. Instrumen dalam penelitian ini adalah pedoman wawancara mendalam dengan informan berjumlah 8 orang. Variabel dalam penelitian ini adalah pengetahuan siswa, sikap siswa dan perilaku siswa yang terkait dengan CTPS. Faktor pendukung terdiri dari sikap dan pengetahuan perilaku. Pengetahuan siswa dalam pengetahuan rendah, karena hanya sebatas tahu. Sikap terhadap perilaku CTPS di SMAN Santa Agnes mendukung CTPS sebagai perilaku sehat yang bermanfaat. Perilaku CTPS di SMAN Santa Agnes kurang, terutama setelah olahraga. Kemungkinan faktor dalam bentuk fasilitas yang sudah baik, tetapi jumlahnya masih belum mencukupi. Faktor penguat dorongan guru untuk melakukan CTPS dan motivasi lingkungan yang terkait dengan tangan yang kotor dapat menyebabkan pengalaman sakit yang telah dialami dan terbiasa dengan CTPS. Kesimpulan yang dapat ditarik adalah bahwa semua informan memiliki beragam perilaku dan risiko terhadap kesehatan mereka. Perilaku malas adalah kunci utama yang harus dilawan agar tidak mengganggu kesehatan.
\end{abstract}

Kata kunci : sabun antiseptik, siswa-siswi SMA, perilaku cuci tangan 


\section{PENDAHULUAN}

Kebersihan kondisi dimana sesuatu terbebas dari kotoran, termasuk debu, sampah dan bau. Indonesia menjadi salah satu negara dengan masalah kebersihan yang terus berkembang, menurut Alfarisi (2008) kasus yang mengenai masalah kebersihan meningkat setiap tahunnya. Terciptanya kesehatan memerlukan kebersihan sebagai salah satu kuncinya.

Menjaga kebersihan diri menjadi penting karena akan berpengaruh terhadap kesehatan. Diharapkan dengan tubuh yang bersih tidak terjadi penyebaran kotoran dan tidak terjadi penularan penyakit, baik bagi individu tersebut atau bagi orang lain. Kebersihan diri merupakan suatu proses pertahanan dan pemeliharaan kebersihan serta kesehatan tubuh. Langkah seseorang untuk dapat memelihara kebersihan dan kesehatan dapat dimulai dengan mandi secara teratur, selalu tampil rapi, merawat gigi secara teratur, memakai selalu pakaian yang bersih dan mencuci tangan memakai sabun antiseptik (Timmreck, 2004).

Pemeliharaan kebersihan dan kesehatan masuk dalam program Perilaku Hidup Bersih dan Sehat (PHBS). Program PHBS adalah usaha yang dilakukan dengan tujuan menambah pengalaman belajar atau mewujudkan keadaan hidup bersih dan sehat di lingkungan perorangan, keluarga, kelompok, dan masyarakat, dengan mengungkapkan alasan dari seseorang untuk mau atau tidak mau melakukan perilaku bersih dan sehat (Janz \& Becker, 1984).

Perilaku CTPS adalah bagian dari program Perilaku Hidup Bersih dan Sehat (PHBS). PHBS menyita bayak perhatian khususnya mengenai perilaku CTPS. Menurut Depkes RI (2008) minimnya praktek CTPS di berbagai negara, mulai dari negara yang sedang berkembang sampai negara maju pun masih masih menjadi masalah. Kesulitan dalam mengatasi masalah CPTS dengan baik sesuai anjuran dikarenakan alasan lupa dan malas menjadi pemicu utama dari tiap individu. PHBS sebagai dasar dalam terwujudnya peningkatan tingkat kesehatan memuat kunci utama dalam hal CTPS. Hal yang harus terus ditingkatkan adalah perilaku CPTS yang benar yaitu cuci tangan dengan air yang mengalir dan sabun antiseptik pada saat setelah buang air besar dan sebelum makan.

CTPS merupakan usaha untuk menjaga kebersihan seluruh bagian tangan dengan media air dan sabun antiseptik sebagai penghilang kotoran. Melakukan CTPS merupakan salah satu usaha pencegahan penyakit yang mudah untuk dilakukan. Perilaku CTPS menjadi penting mengingat fungsi dari tangan yang sering kontak dengan tubuh sendiri atau orang lain baik secara langsung maupun menggunakan media atau kontak tidak langsung. Bahaya muncul apabila kontak dilakukan dalam kondi tangan yang sedang kotor, hal ini dapat memicu penyebaran penyakit melalui pemindahkan bakteri, virus, dan parasit dari satu orang ke orang lain tanpa disadari. WHO sangatlah serius dengan masalah CTPS hingga tanggal 15 Oktober diperingati sebagai Hari Mencuci tangan pakai sabun antiseptik Sedunia. Indonesia menjadi satu dari 20 negara dari seluruh negara di dunia sebagai pendukung gerakan CTPS (WHO, 2009).

Pengetahuan adalah merupakan hasil dari tahu dan ini terjadi setelah orang melakukan penginderaan terhadap obyek tertentu. Penginderaan terhadap obyek terjadi melalui panca indera manusia, yakni: penglihatan, pendengaran, penciuman, rasa, dan raba. Sebagian besar pengetahuan manusia diperoleh melalui mata dan telinga (Notoatmodjo, 2007).

Sikap adalah respons tertutup seseorang terhadap stimulus atau objek tertentu. Sebagai contohnya yang sudah melibatkan faktor pendapat dan emosi yang bersangkutan atau senang-tidak senang, setuju-tidak setuju, baik-tidak baik, dan sebagainya (Notoatmodjo, 2010).

Tindakan adalah mekanisme dari suatu pengamatan yang muncul dari persepsi sehingga ada respon untuk 
mewujudkan suatu tindakan. Kebiasaan setiap anak dalam berperilaku mencuci tangan dengan sabun antiseptik agar terhindar dari berbagai macam penyakit sehingga dapat diterapkan dalam kegiatan sehari-hari.

Kebiasaan setiap anak dalam berperilaku CTPS dengan benar perlu ditanamkan sejak dini. Keyakinan yang terbentuk dari perilaku CTPS agar terhindar dari berbagai macam penyakit dapat menjadi bentuk penerapan yang sering dijumpai setiap harinya. Demi memperoleh hasil yang maksimal, maka mencuci tangan hendaknya menggunakan air bersih yang mengalir dengan menggunakan sabun antiseptik, kemudian dikeringkan dengan handuk bersih atau menggunakan tisu (Kemenkes, 2010).

Siswa-siswi di SMAK Santa Agnes Surabaya sering melakukan kegiatan olah raga di pagi hari yang dilanjutkan dengan sarapan bersama. Kebiasaan yang sangat buruk di kalangan siswa-siswi SMAK Santa Agnes Surabaya adalah lupa untuk mencuci tangannya dengan sabun antiseptik sebelum mengkonsumsi makanan. Depkes RI (2009) menyatakan penyakit yang timbul jika tidak melakukan CTPS adalah infeksi saluran pernapasan karena tidak melakukan CTPS akan menimbulkan kuman pernapasan yang ada pada tangan dan permukaan telapak tangan, kuman tersebut tidak akan menghilang dan masuk kedalam tubuh. Diare penyakit selanjutnya yang timbul dari perilaku tidak melakukan cuci tangan pakai sabun antiseptik karena kuman penyebab diare ditularkan melalui fecal-oral. Penelitian telah membuktikan bahwa selain diare dan infeksi saluran pernapasan, tidak menggunakan sabun antiseptik saat mencuci tangan dapat meningkatkan kejadian penyakit kulit, infeksi mata, dan cacingan.

Perilaku cuci tangan pakai sabun antiseptik merupakan salah satu dari program PHBS di lingkungan sekolah. Program PHBS dilakukan dalam usaha untuk memberdayakan tiap individu khususnya siswa-siswi SMA Santa Agnes
Surabaya agar sadar, mau, dan mampu untuk membiasakan hidup bersih dan sehat. Pelajar berperan dalam gerakan kesehatan di masyarakat agar tercipta pemeliharaan kesehatan, peningkatan kesehatan serta pencegahan risiko terjadinya penyakit (DepkesRI, 2009).

CTPS dapat mencegah infeksi cacingan. Cuci tangan tidak menggunakan sabun antiseptik, dapat menularkan infeksi pada diri sendiri terhadap bakteri dan virus dengan memegang bagian hidung, mata dan mulut. Selain itu juga dapat menyebarkan atau menularkan bakteri kepada orang lain. Penyakit infeksi biasanya terjangkit melalui kontak tangan ke tangan termasuk flu dan common cold. Pada tangan yang kurang bersih tidak hanya dapat menyebabkan ISPA dan diare tetapi juga dapat menimbulkan penyakit terkait infeksi bakteri Salmonella dan E.coli (Lestari, 2008).

Mencuci tangan umumnya dilakukan dengan air, karena terbukti dengan melakukan cuci tangan menggunakn air saja kurang efektif untuk menghilangkan kuman di tangan dibandingkan dengan mencuci tangan dengan sabun antiseptik. Cuci tangan menggunakan sabun antiseptik sebenarnya menyebabkan orang harus meluangkan waktu lebih lama, namun penggunaan sabun antiseptik mampu membersikan lemak dan kotoran yang menempel di telapak tangan. Lemak dan kotoran yang menempel pada telapak tangan akan terlepas saat tangan digosok dan bergesekan, sehingga akan lebih efektif untuk menghilangkan lemak dan kotoran serta kuman. Lemak dan kotoran yang menempel inilah menjadi tempat kuman penyakit hidup. Penggunaan hand sanitaiser tidaklah salah akan tetapi sebaiknya mencuci tangan dengan sabun antiseptik agar kuman yang terdapat pada tangan dapat hilang sepenuhnya. Penelitian ini bertujuan untuk menganalisis faktor yang mempengaruhi siswa-siswi di SMAK Santa Agnes Surabaya terkait perilaku tidak CTPS. 


\section{METODE PENELITIAN}

Penelititan ini menggunakan metode penelitian kualitatif dengan pendekatan fenomenologi. Penggunaan metode ini dengan alasan bahwa fokus dalam penelititan ini adalah perilaku tidak cuci tangan pakai sabun antiseptik. Pendekatan fenomenologi bertujuan untuk menggambarkan makna dari pengalaman hidup yang dialami oleh beberapa individu, tentang konsep atau fenomena tertentu, dengan mengeksplorasi struktur kesadaran manusia.

Jenis penelitian yang digunakan adalah penelitian deskriptif dengan tujuan untuk menggambarkan suatu obyek yang berhubungan dengan masalah yang diteliti, tanpa mempersoalkan hubungan antar variabel. Pendekatan kualitatif digunakan peneliti hanya untuk memahami sebuah fakta yang ada di lapangan, dan bukan untuk menjelaskan fakta yang ada.

Sumber data pada penelitian ini berasal dari informan. Informan penelitian ini adalah siswa - siswi SMAK Santa Agnes Surabaya yang tidak mencuci tangannya dengan sabun antiseptik setelah berolah raga atau sebelum mengkonsumsi makanan. Siswa - siswi yang menjadi informan tersebut berusia antara $15-17$ tahun. Serta para guru yang akan dilakukan wawancara mendalam guna untuk mengcross check tentang kebenaran data yang telah didapat.

Penentuan informan dengan teknik ini adalah dengan mengambil informan secara accidental atau secara bebas oleh peneliti sesuai dengan kriteria informan yang diperlukan untuk penelitian. Informan dipilih oleh peneliti karena aksesibilitas rasa nyaman serta kedekatan informan dengan peneliti.

Instrumen pengumpulan data untuk penelitian ini berupa pedoman wawancara dan lembar observasi. Pedoman wawancara ini berisikan beberapa pertanyaan yang akan ditanyakan pada informan yaitu siswasiswi. Lembar observasi berisikan tentang poin fasilitas yang terdapat di SMAK Santa
Agnes dan perilaku yang dilakukan oleh siswa-siswi terkait CTPS. Teknik analisis data yang digunakan dalam penelitian ini adalah menggunakan langkah-langkah sebagai berikut : Pengumpulan data (Data Collection), Reduksi data (Data Reduction), Penafsiran data dan Analisis dengan penarikan kesimpulan dan saran serta triangulasi data. Triangulasi yang digunakan pada penelitian ini adalah triangulasi sumber yaitu berupa siswa dan guru. Serta triangulasi teknik berupa observasi dan wawancara.Batas akhir dari penelitian ini tidak ditentukan, dikarenakan peneliti harus mengikuti proses penelitian itu sendiri. Peneliti mengakhiri pengumpulan data setelah mendapatkan semua informasi yang dibutuhkan, atau pada saat melakukan penelitian peneliti sudah tidak menemukan data baru lagi, dan peneliti sudah mengalami kejenuhan data.

\section{HASIL DAN PEMBAHASAN}

\section{Karakteristik Informan}

Informan penelitian ini adalah siswa - siswi SMAK Santa Agnes Surabaya berusia $15-17$ tahun yang tidak mencuci tangannya dengan sabun antiseptik setelah berolah raga atau sebelum mengkonsumsi makanan.

\section{Faktor Pendorong \\ Pengetahaun Cuci tangan pakai sabun antiseptik}

Sebagian besar informan mengatakan manfaat cuci tangan adalah untuk menghilangkan kuman dan kotoran agar bakteri tidak masuk dan tidak sakit.

"Supaya kalo ada kuman gitu bisa terhindar dari penyakit" Informan 6, 15 tahun

"Bisa ngilangin kuman yang pertama, yang kedua bisa ngilangin kotoran" Informan 7, 17 tahun

"Yah kalo mau makan gitu supaya bakterinya ngga masuk" Informan 8, 16 tahun. 
Informan berpendapat bahwa bahaya yang dapat timbul akibat dari tidak mencuci tangan pakai sabun antiseptik adalah sakit perut seperti mules, diare dan keracunan

"Iya, bisa sakit perut, sakit perut mules mules gitu terus sering kekamar kecil" Informan 2, 15 Tahun

"Iya, kalok misal e habis megang bahan kimia kan bisa keracunan terus isa sakit perut, sakit perut e mencret gitu" Informan 5, 15 Tahun

"Yah tau, bisa kena diare" Informan 6, 15 Tahun.

Ada juga informan yang berkata tidak mengetahui bahaya dari tidak mencuci tangan pakai sabun antiseptik.

"Gatau sih kalo bahayanya hehe" Informan 7, 17 Tahun.

Informan melaksanakan cuci tangan pada umumnya sebelum dan setelah makan, informan lain menambahkan pas mandi, setelah olahraga, saat akan cuci muka dan saat akan tidur. Terdapat 1 informan yang menjawab cukup banyak yaitu setelah dari kamar kecil atau toilet, setelah memegang sampah setelah praktikum tetapi tidak menyebutkan setelah makan atau sebelum makan.

"Selesei makan terus sebelum makan juga pas mandi" Informan 1, 15 Tahun

"Setelah dan sebelum makan setelah melakukan kegiatan setelah dari kamar kecil" Informan 4, 16 tahun

"Setelah ketoilet terus setelah megang sampah atau habis dari apa yaa praktikum atau apalah" Informan 5, 15 Tahun

"Sebelum makan terus kalo abis olahraga mau cuci muka kan cuci tangan dulu" Informan 6, 15 tahun

"Saat mau makan dan saat mau tidur" Informan 8, 16 tahun

Informan memahami bahwa jumlah langkah CTPS yang baik adalah 3 langkah, 4 langkah atau 6 langkah. Semua informan tidak mengetahui berapa langkah CPTS yang baik sesuai dengan anjuran WHO.

"Umm kalo aku liat di rumah sakit itu ada 3 atau 4" Informan 115 Tahun

"4 atau 3 langkah gitu” Informan 215 Tahun

"Ada 4 langkah ko" Informan 315 Tahun

"Umm berapa ya 6 paling hehe" Informan 416 Tahun

"Ya pokok e 3 langkah" Informan 515

Tahun

"Ada 3 sih" Informan 615 Tahun

“Ada 3” Informan 717 Tahun

\section{Sikap terhadap perilaku Cuci tangan pakai sabun antiseptik}

Semua informan bersikap positif terhadap perilaku CPTS, mereka merasa bahwa cuci tangan dapat membersikan tangan mereka dari kuman sehingga dapat membantu menjaga kesehatan.

"Ya bagus sih buat hilangin kuman" Informan 1, 15 Tahun

"Biar bersih biar kumannya ngga ada

"Informan 2, 15 Tahun

“Apa yaa umm kebersihan” Informan 416 Tahun

"Yah cuci tangan tuh bermanfaat bagi kesehatan” Informan 8, 16 Tahun

\section{Perilaku Cuci tangan pakai sabun antiseptik}

Perilaku CTPS dalam penelitian ini meliputi kebiasaan cuci tangan memakai sabun antiseptik, langkah yang digunakan, kebiasaan CTPS setelah berolahraga, kebiasaan mengkonsumsi makanan setelah berolahraga. Berdasarkan hasil wawancara mendalam sebagian besar siswa-siswi mencuci tangan memakai sabun antiseptik, hanya ada 3 Informan yang menjawab kalau tidak males dan kadang.

"Kalo ngga males pake sabun antiseptik hehe" Informan 5, 15 Tahun

"Ya kadang sih" Informan 6, 15 Tahun 
"Kadang iya kadang engga sering engganya sih hehe” Informan 8, 16 Tahun

Hasil wawancara untuk jumlah langkah yang digunakan saat mencuci tangan masil belum sesuai dengan anjuran WHO sebanyak 7 langkah. Sebagian besar dari mereka melakukan 4 atau 3 langkah saja.

"Langkah sih ya 3 langkah” Informan 1, 15 Tahun

"4 langkah" Informan 2, 15 Tahun

"3 langkah saat cuci tangan" Informan 3 15 Tahun.

"Ngga ngitung sih ngasal aja mungkin 2 atau 3 langkah” Informan 4, 16 Tahun

Hasil penelitian tentang perilaku CTPS setelah berolahraga menunjukkan bahwa sebagain besar dari siswa-siswi tidak melakukan CTPS setelah melakukan olahraga

"Ngga cuci tangan" Informan 1, 15 Tahun "Kadang iya kadang engga tapi banyak engganya hehe” Informan 7, 17 Tahun

Hasil wawancara mendalam untuk perilaku CPTS setelah melakukan olahraga, ditanyakan kebiasaan konsumsi makanan setelah melakukan olahraga. Sebagian besar mengatakan bahwa mereka langsung makan setelah melakukan kegiatan olahraga tanpa mencuci tangan dengan sabun antiseptik terlebih dahulu. Hal ini tidak baik untuk kesehatan tubuh, karena dapat menyababkan sakit perut (diare) yang tidak di ingingkan.

"Iya makan makanan ringan sih kayak snack" Informan 3, 15 Tahun

"Iya ko, aku beli nasi kadang hehe" Informan 4, 16 Tahun

"Iya, aku beli roti kalo ngga yah makan nasi ato beli mie ayam hehe" Informan 8, 16 Tahun.

Terdapat informan yang hanya kadang makan setelah olahraga atau bahkan tidak makan.
"Kadang iya kadang engga sih, tapi kalo ngga makan pas berangkat jadi e aku beli nasi hehe” Informan 5, 15 Tahun.

\section{Faktor Pemungkin}

Sebagian besar informan
mengatakan bahwa sekolahan tidak
menyediakan fasilitas yang baik untuk
menunjang perilaku CPTS para siswa-siswi,
sehingga pasa siswa hanya menggunakan
air saja atau tissue basah untuk
membersihkan tangannya yang kotor
tersebut.

"Ya karena ngga ada sabun antiseptik jadinya ngga cuci tangan. Pake tissue basah sih biasanya jadi ngga perlu cuci tangan lagi" Informan 3, 15 Tahun

"Umm males mungkin dan juga karena fasilitas e kurang buat cuci tangan terus ya jarang ada sabun antiseptiknya juga, dan juga males itu tadi hehe" Informan 4, 16 Tahun

"Yah rasa e sabun antiseptik yang ada di sekolah itu rodok kurang meyakinkan gitu" Informan 7, 17 Tahun.

\section{Faktor Penguat, Pendorong, dan penghambat dalam cuci tangan pakai sabun antiseptik}

Sebagian informan mengatakan bahwa aktivitas yang membuat tangan kotor menjadi pendorong untuk melakukan CTPS. Terdapat informan yang mengatakan sering sakit sehingga selalu mencuci tangan.

"Kalo misal e tangan e kotor cuci tangan biar kalo misal e mau makan pake tangan biar ngga ada kuman yang masuk"

Informan 2, 15 Tahun

"Soal e kan aku sering sakit perut jadi e aku harus cuci tangan, sakit perut e mules mules gitu tapi bukan haid" Informan 3, 15 Tahun

"Umm ya kalo kita habis melakukan sesuatu kan tangan e kotor ya jadi e cuci tangan" Informan 4, 16 Tahun 
Hasil wawancara mendalam terkait denagan hambatan saat mencuci tanagn menggunakan sabun antiseptik lebih mengarah ke malas dengan berbagai alasan dan menganggap bahwa tangan mereka tidak kotor meskipun setelah melakukan aktivitas. Secara kasap mata, tangan tidak kotor maka mereka menganggap tangan mereka bersih.

"Mikirnya ga kotor tangannya" Informan 2, 15 Tahun

"Makan chiki atau makan makanan yang ada bungkusnya jadi ga perlu cuci tangan" Informan 3, 15 Tahun.

"Umm kalo kayak mungkin ngga lagi ngelakuin sesuatu no activity” Informan 4, 16 Tahun.

"Pemikiran kalo orang miskin ajah ngga cuci tangan ngga sakit gitu jadinya yah males buat cuci tangan" Informan 8, 16 Tahun.

\section{PEMBAHASAN}

\section{Faktor Pendorong dan Pengetahuan}

Berdasarkan hasil observasi tidak terihat poster atau himbauan untuk melakukan CTPS dengan baik. Belum adanaya program CPTS di lingkungan sekolah membuat siswa-siswi kebingungan untuk menjawab pertanyaan wwancara dan terlhat dari pengetahuan siswa-siswi yang kurang

Sebagian besar siswa-siswi mengatakan bawha CTPS mempunyai manfaat terhadap kebersihan dan kesehatan pada diri merekan. Manfaat yang dirasakan setelah melaukan CTPS membuat informan berperilaku positif terhadap cuci tangan. Seseorang melakukan suatu perilaku akan mempertimbangkan menfaat yang didapat. Apakah perilaku tersebut memiliki manfaat yang baik untuk dirinya sendiri atau tidak.

Mencuci tangan menjadi salah satu cara preventif suatu penyakit yaitu dengan jalan menghilangkan kuman penyakit yang menempel di bagian tangan yang mengakibatkan tangan bersih dan bebas kuman. Menurut Proverawati dan
Rahmawati (2012) tangan dengan kondisi bersih dapat menghindarkan seseorang dari terjangkit penyakit diare, cacingan, penyakit kulit, Infeksi saluran pernafasan akut (ISPA) dan flu burung.

Indikasi waktu untuk mencuci tangan menurut Kemenkes RI (2013) yaitu setiap kali tangan kita kotor, setelah BAB (buang air besar), sebelum memegang makanan, setelah bersin, batuk, membuang ingus, Setelah pulang dari bepergian dan Setelah bermain. Pada intinyaa aktifitas yang dapat menimbulkan kotoran atau kuman menjdi waktu wajib untuk mencuci tangan. Temuan diatas tidak sesui dengan perilaku CTPS yang dianjurkan oleh WHO. Menurut WHO (2008) langkah mencuci tangan yang benar berjumlah 7 langkah. Langkah tersebu adalah basuh tangan dengan air bersih yang mengalir, ratakan sabun antiseptik dengan kedua telapak tangan sebagai langkah awal. Selanjutnaya, gosok punggung tangan dan sela jari tangan kiri dan tangan kanan, begitu pula sebaliknya. Ketiga, gosok kedua telapak dan sela - sela jari tangan, Keempat, jari jari sisi dalam kedua tangan saling mengunci, Kelima, gosok ibu jari kiri berputar dalam genggaman tangan kanan dan lakukan sebaliknya. Keenam, gosokkan dengan memutar ujung jari-jari tangan kanan di telapak tangan kiri dan sebaliknya. Ketujuh, bilas kedua tangan dengan air yang mengalir dan keingkan

Menurut (Notoatmodjo, 2003), pengetahuan dapat masuk dalam 6 tingkatan, yaitu: Tahu, Memahami, Aplikasi, analisis Sintesis Evaluasi. Tingkat pengetahuan dari siswa-siswi SMAK Santa Agnes masuk dalam kategori tahu, karena dari hasil wawancara sebagian besar siswa hanya mengingat atau menjawab setahunya. Dapat dikatakan bahwa siswa-siswi SMAK santa Agnes hanya sekedar tahu.

Hasil wawancara menunjukkan siswa-siswi belum dapat menjelaskan apa itu CTPS. Hal itu terlihat dari hasil wawancara yang menunjukkan jawaban yang kurang tepat pada pertanyaan jumlah langkah cuci tanagan. Dan siswa-siswi 
tidak dapat menyebutkan sebagian dari seluruh waktu yang tepat untuk cuci tangan yang dianjurkan oleh kemenkes.

Menurut Tarwoto dan Wartonah (2004) faktor yang berpengaruh terhadap seseorang untuk berperilaku CTPS adalah seberapa besar pengetahuan yang dimiliki. Guru memegang tanggung jawab penuh disekolah untuk mengajarkan perilaku CTPS di sekolah. Pengetahuan siswa tentang mencuci tangan yang diperoleh dari guru, diantaranya tentang waktu dan cara mencuci tangan. Pengetahuan tersebut dapat di publikasikan tidak hanya saat jam mengajar namun juga memfasilitasi poster yang berisi anjuran untuk CTPS Sehingga karena kurangnya pengetahuan dari tiap siswa-siswi tentang pengetahuan CTPS akan menyebabkan perilaku mencuci tangan siswa relatif kurang.

Berdasarkan hasil penelitian Risnawati (2016) pada masyarakat dengan tingkat pengetahuan terhadap perilaku CTPS termasuk tinggi, namun perilaku CTPS masuk dalam kategori rendah, sehingga pengetahuan belumtentu menjadi faktor penentu masyarakat untuk berperilaku CTPS. Menurut wawan (2011) seseorang dengan pengetahuan tertentu tidak menjamin kalau dia akan berperilaku sesuai dengan apa yang dia ketahui sebelum orang tersebut melewati tahap dari awal hingga akhir sampai dapat menerapkan pengetahuan tersebut.. hal ini diperparah dengan kondisi pengetahuan siswa-siswi yang rendah tentang CTPS.

Pengetahuan yang dimilki seseorang dapat bersumber dari pendidikan formal yang pernah dijalani, pengalaman yang pernah dilalui, interaksi sosial dengan lingkungan sekitar dan akses informasi dari media masa. Sebagian besar informan berpendapat mendapatkan terdapat mafaat dari perilaku CTPS sehingga terbentuk pengetahuan yang baik mengenai manfaat perilaku CTPS dan bahaya apabila tidak melakukan CTPS (KemenkesRI, 2014). '

Lingkungan sekitar dimana setiap harinya menjadi temapt untuk beraktifitas memberikan pengalaman yang berbeda pada setiap individu tergantung daya tangkap individu tersebut. Media tenpat medapatkan informasi biasannya adalah buku, media massa, media elektronik, poster, saodara atau petugas kesehatan. Kegiatan kesehatan yang mendidik melalui penyuluhan kesehatan dapat memberikan informasi dengan jangkauan yang luas , sehingga dapat menambah wawasan dan pengetahaun. Diharapkan dengan menyatu dengan lingkungan sekitar seseorang dapat memperoleh informasi tentang perilaku CTPS.

\section{Sikap}

Sikap merupakan reaksi tak terlihat, bersifat intagible,sebagai langkah untuk bersiapa atau bersedia untuk melakukan sesuatu. Sikap belum memunculkan suatu tindakan yang nyata, namun hanya faktor pendorong dari suatu tindakan atau perilaku (Wawan dan Dewi, 2011). Sikap biasanya diukur menggunakan dua cara yaitu secara langsung dan secara tidak langsung. Menanyakan melalui kegiatan wawancara untuk menggali pendapat seseorang mengenai suatu objektermasuk kedalam pengukuran secara langsung. Penelitian ini dilakukan dengan mewawancarai perilaku CTPS informan dengan hasil sebagian besar responden mendukung akan perilaku CTPS.

Sikap adalah bagain tervital dalam psikologi sosial sesorang yang menerangkan respon sebagain individu ataupun kelompok. Menurut wawan dan Dewi (2011) Studi terus dilakukan guna memperoleh rumusan yang tepat dan mengikuti perkembangan jaman tentang pengertian, proses terbentuknya dan perubahan dari sikap itu sendiri. Penelitian sering dilakukan untuk membuktian kaitan atau pengaruh antara sikap dalam membentuk karakter seseorang, interaksi dengan individu lain atau kelompok yang menimbulkan berbagai pilihan sikap yang menyesuaikan dengan lingkungan serta perubahan yang mungkin terjadi (Wawan dan Dewi, 2011).

Hasil wawancara mendalam dan observasi yang dilakukan menunjukkan 
bahwa siswa-siwi mempunyai sifat sikap yang positif yaitu kecenderungan tidakan untuk mendekati menyatakan dan mengharap objek tertentu. Sikap dari Siswa-siswi yang berada dilingkungan sekolah sangatlah dipengaruhi oleh pengalaman pribadi. Siswa-siswi berpendapat bahwa dengan muncuci tangan mereka dapat merasakan hasilnya sendiri tanpa perlu pengaruh dari luar untuk membuktikan manfaat dari perilaku CTPS.

Temuan studi ini menunjukkan beberapa informan merasa rentan terhadap penyakit sehingga membuat informan bersikap positif terhadap cuci tangan. Sikap positif ini belum memunculkan perilaku cuci tangan seperti yang diharapkan, yakni pada waktu setelah olahraga. Sesuai dengan teori yang digunakan, ancaman (kerentanan dan keparahan) yang dirasakan oleh siswasiswi masih kurang.. Notoatmodjo (2010) menyatakan bahwa terwujudnya suatu tindakan bukan hanya akibat dari sikap seseorang terhadap suat objek.sikap dapat terwujud kedalam suatu tindakan membutuhkan lingkungan yang menunjang berupa fasilitas layak

Penilaian diambil melalui pendapat seseorang terhadap suatu objek dalam hal ini adalah masalah kesehatan khususnya perilaku cuci tangan pakai sabun antiseptik, termasuk penyakit akibat tidak melakukan CTPS yang dipernah dialami maupun hanya sebatas pengetahuan adalah aspek yang masuk dalam penilaian sikap seseorang. Diharapkan informan dapat menggali pengalam yang pernah diaami, pengaruh orang lain dan medai sosial terkait dengan perilaku CTPS, sehingga akan terlihat bagaimana seseorang menilai atau bersikap terhadap perilakuk CTPS. Kombinasi dari pengetahuan yang kurang dengan sikap yang mendukung perilaku CTPS. Hasilnya terlihat perilaku CTPS yang masih rendah di SMAK Santa Agnes yang tidak sesuai dengan harapan kerena kurangnya kesadaran individu.

\section{Perilaku}

Perilaku "malas dan tidak punya waktu untuk mencuci tangan" seperti alasan informan tidak hanya bersumber dari pengetahuan dan keyakinan, tetapi juga faktor "kecukupan waktu" yang secara konsep merupakan faktor yang memungkinkan untuk timbulnya perilaku (Notoatmodjo, 2009). Menurut informan, mereka tidak mempunyai waktu yang cukup untuk mencuci tangan pakai sabun antiseptik. Dasar pengetahuan yang kurang baik dan tidak didukung oleh waktu yang cukup, maka akan mempengaruhi terjadinya perilaku tidak cuci tanagan.

Temuan perilaku cuci tangan pakai sabun antiseptik menunjukkan bahwa sebagian besar informan tidak ada yang menjalankan perilaku cuci tangan pakai sabun antiseptik setelah olahraga. Mencuci tangan sebelum dan sesudah makan dilakukan oleh sebagian besar informan, namun tidak sama halnya setelah melakukan olahraga yang dilanjutkan makan. Perilaku para informan pelajar ini tidak konsisten dengan pengetahuan tentang waktu mencuci tangan yang menjadi patokan Depkes RI (2009). Pengetahuan informan yang tidak cukup tentang "cara" cuci tangan pakai sabun antiseptik ternyata menghasilkan perilaku ", terus ga cuci tangan pakai sabun antiseptik juga ngga ada masalah jadi yah ngga pake sabun antiseptik deh hehe".

Penelitian yang dilakukan oleh Lindawati (2013) yang mengatakan bahwa guru mempunyai kesempatan untuk mengarahkan perilaku anak didiknya disekolah melalui pembuatan aktivitas yang dikemas menarik baik dalam jam sekolah ataupun diluar jam sekolah yang dengan tujuan agar para siswa memperhatikan. Aktivitas yang dibuat oleh guru harus dapat menyalurkan perilaku CTPS yang baik dan benar karena perhatian siswa-siswi terhadap suatu hal dipengaruhi oleh guru, lingkungan, orang tua, saudara dan teman bermainnya.

Rabbi dan Dey (2013) menyatakan untuk mengatasi masalah kesenjangan antara pengetahuan dengan praktik CTPS 
memerlukan usaha yang memakan waktu lama sebagai langkah dalam perbaikan PHBS melalui CTPS. Program CTPS sudah dicanangkan dalam kurun waktu yang lama, namun melihat fakta yang ada perilaku CTPS di lingkungan sekolah sangatlah rendah. Padahal sekolah merupakan tempat membentuk karakter dari siswa-siswi yang ada didalamnya sehingga kegiatan promosi kesehatan dibidang CTPS secara rutin dilakukan sebagai upaya peningkatan derajad kesehatan melalui kesadaran siswasiswi untuk melakukan CTPS.

Penelitian yang dilakukan oleh World Health Organization (WHO) tentang usaha penurunan angka kejadian diare dan ISPA melaui peningkatan perilaku CTPS di masyarakat. Tindakan yang dilakukan adalah melalui langkah CTPS yang telah dianjurkan oleh WHO. Tidakan tersebut dilakukan untuk menghilangkan kuman dan penyakit sehinga kejadian diare dan ISPA dapat turun. Penelitian yang dilakukan oleh Risnawati (2016) menunjukkan bahwa hasil yang lebih efektif dalam menghilangkan kuman terlihat pada responden yang melakukan cuci tangan menggunakan sabun antiseptik dari pada hanya dengan air saja. Dalam penelitian ini sekolahan dan rumah di lingkungan sekitar sudah dilengkapi dengan cara CTPS yang baik.

\section{Faktor Pemungkin}

Faktor pemungkin yang terdapat di lingkungan sekolah, terdapatnya fasilitas CTPS yang sudah baik dan layak untuk mendukung terciptanya perilaku CTPS. Hasil observasi menunjukkan fasilitas yang minim dilingkungan sekolah. Terlihat dai jawaban informan yang tidak singkron dengan hasil observasi. Meskipun sudah terdapat sarana atau fasilitas CTPS pada kenyataannya belum dapat merubah atau mendukung perilaku para siswa untuk bercuci tangan pakai sabun antiseptik di sekolah.

Temuan studi ini menunjukkan bahwa keyakinan dari siwa-siswi untuk melakukan CPTS sudah ada disertai dengan fasilitas memadai dari pihak sekolah.
Didasari keyakinan menyangkut CPTS, maka perilaku muncul menyesuaikan keyakinan yang dimiliki informan. keyakinan akan kemampuan individu akan menggerakkan motivasi, kemampuan kognitif, dan tindakan yang diperlukan untuk memenuhi tuntutan situasi (Ghufron, 2014). Perlu disadari bahwa keyakinan kecakapan diri adalah persepsi spesifik tentang kemampuan seseorang untuk melakukan perilaku tertentu yaitu perilaku untuk melakukan CTPS.

\section{Faktor Penguat}

Faktor penguat yang terwujud dalam sikap dan perilaku guru SMAK Santa Agnes menjadi panutan bagi terbentuknya perilaku para siswa. Perlunya dilakukan program promotif dan preventif kesehatan yang efektif melalui perilaku CTPS di lingkungan sekolah. Pihak sekolah hendaknya lebih meningkatkan program promosi kesehatan rutin dan membuat pelatihan bagi siswa terkait seperti, anggota UKS, OSIS dan bidang lain yang terkait, diharapkan terbentuk perilaku CTPS di kalangan sekolah dengan para anggota UKS, OSIS dan bidang lain yang terikat menjadi contoh sekaligus mengajari temannya. Diluar itu guru juga menjadi panutan bagi pasa siswa tentang perilaku hidup bersih dan sehat (Notoatmodjo, 2010).

Penelitian ini menggunakan sekolah dalam hali in SMAK Santa Agnes sebagai tempat observasi. Peran guru menjadi paling dominan dalam mengarahkan perilaku CTPS para siswa diluar penyuluhan oleh tenaga kesehatan setempat. Hasil observasi dan wawancara mendalam saat kegiatan olahraga berlangsung dan setelah selesai melakukan olahraga menunjukkan minimnya peran guru sebagai penguat dari perilaku CTPS. Perilaku telihat dari banyaknya siswa-siswi yang tidak melakukan cuci tangan setelah olahraga. 


\section{SIMPULAN}

Faktor Pendorong berupa Siswasiswi memiliki pengetahuan yang kurang mengenai CTPS. Seluruh siswa-siswi hanya sebatas tahu tentang CTPS akan tetapi siswa-siswi tidak dapat menyebutkan dengan benar terkait langkah cuci tangan yang baik dan benar sesuai dengan anjuran dari WHO. Manfaat yang dirasakan oleh siswa-siswi terkait dengan CTPS yaitu menghilangkan kuman dan bakteri.

Sikap siswa-siswi mendukung jika CTPS merupakan hal yang baik dan bermanfaat. Perilaku CTPS dilingkungan sekolah masih kurang meskitpu setelah melakukan aktifitas kotor berupa olahraga. Kebiasaan siswa-siswi terkait CTPS kurang baik, dikarenakan siswa-siswi mengatakan bahwa saat hendak mengkonsumsi makanan seharusnya melakukan CTPS terlebih dahulu. Akan tetapi setelah berolah raga, siswa-siswi tersebut langsung mengkonsumsi makanan tanpa melakukan CTPS terlebih dahulu

Faktor pemungkin agar siswa-siswi SMAK Santa Agnes dalam perilaku CTPS adalah tersediannya fasilitas CTPS yang baik, namun masih belum memadai jika dilihat dari jumlahnya. Fator Penguat perilaku CTPS di SMAK Santa Agnes adalah dukungan dari guru berupa motivasi.

\section{DAFTAR PUSTAKA}

Alfarisi, 2008. Pentingnya Menjaga kebersihan. Diakses 21 Desember 2017.

DepKes RI. 2008. Panduan Manajemen PHBS Menuju Kabupaten/Kota Sehat. Jakarta : Departemen Kesehatan RI.

DepKes RI. (2009). Panduan Penyelenggaraan Cuci tangan pakai sabun antiseptik Sedunia (HCTPS). Jakarta: Departemen Kesehatan RI

Ghufron. 2014. Teori Psikologi. Yogyakarta: Ar Ruzz Media.

Janz, N.K. and Becker, M.H. 1984. The Health Belief Model A Decade
Later, Health Education

Quarterly;11:1-47.

Kemenkes RI. 2010. Profil Kesehatan

Indonesia. Jakarta: Kementrian

Kesehatan Republik Indonesia.

Kemenkes, R.I. 2013. Profil Kesehatan Indonesia. Jakarta: Kementrian Kesehatan Republik Indonesia.

Kemenkes, R.I. 2014. Profil Kesehatan Indonesia. Jakarta: Kementrian Kesehatan Republik Indonesia.

Lestari, D. 2008. Metode Expository Teaching terhadap Perilaku CTPS, Universitas Katolik Soegijapranata, Semarang.

Lindawati. 2013. Faktor yang Berhubungan dengan Perkembangan Motorik Anak Usia Pra Sekolah, Jurnal Keperawatan, 4(1):1-7

Notoatmodjo. S. 2003. Pendidikan dan Perilaku Kesehatan. Jakarta: PT Rineka Cipta

Notoatmodjo, S. 2007. Promosi Kesehatan dan Ilmu Perilaku. Jakarta: Rineka Cipta.

Notoatmodjo, S. 2010. Metodologi Penelitian Kesehatan. Jakarta: Rineka Cipta.

Proverawati A., Rahmawati E.. 2012. Perilaku hidup bersih dan sehat (PHBS). Yogyakarta: Nuha Medika.

Rabbi, E.S and Dey, N.C. 2013. Exploring the gap between handwashing knowledge and practice in Bangladesh, a cross-sectional comparative study, BMS Public Health. 13(89):2-7

Risnawati, G. 2016. Faktor Determinan Perilaku Cuci tangan pakai sabun antiseptik (CTPS) pada Masyarakat di Tanah Kali Kedinding. Jurnal Promkes, Juli 2016; 4:70-81.

Tarwoto, Warwonah. 2004. Kebutuhan Dasar Manusia dan Proses Keperawatan Edisi ketiga. Jakarta : Salemba Medika.

Timmreck, T. C. 2004. Epidemiologi Suatu Pengantar Edisi Kedua (Mulyana Fauziah). Jakarta: EGC. 
Wawan A. and Dewi M. (2011). Teori dan Pengukuran Pengetahuan, Sikap, dan Perilaku Manusia. Cetakan II. Yogyakarta: Nuha Medika.

Wawan. 2011. Teori dan Pengukuran Pengetahuan, Sikap dan Perilaku
Manusia. Yogyakarta: Nuha Medika.

WHO and Unicef. 2008. Progress on Drinking and Sanitation. Geneva: Unicef \& WHO.

WHO. 2009. Guidelines on Hand Hygiene in Healthcare. Geneva: WHO. 